SAKHNO L.O. ${ }^{\boxplus}$, LYSTVAN K.V. ${ }^{2}$

${ }^{1}$ SI "Institute of Food Biotechnology and Genomics» NAS of Ukraine, Ukraine, 04123, Kyiv, Osipovskogo str., 2A, e-mail: sakhno2007@ukr.net

${ }^{2}$ Institute of Cell Biology and Genetic Engineering NAS of Ukraine, Ukraine, DSP-22, 03680, Kyiv, Zabolotnogo str., 148, e-mail: lystvan@ukr.net

凶sakhno2007@ukr.net, (099) 446-74-74

\title{
ANTIOXIDANT ACTIVITY IN BRASSICA NAPUS L. PLANTS EXPRESSING $L O X$-DEPENDENT BAR GENE
}

Production of reactive oxygen species, including free radicals, is an integral part of plant metabolism. Antioxidant activity of plant tissues characterizes an ability to overcome excessive amounts of compounds such as superoxide and hydroxyl radicals, singlet oxygen, and hydrogen peroxide. It is provided by various antioxidant systems. There are enzymes (superoxide dismutase (SOD), peroxidase, catalase) and non-enzyme (proline, glutathione, ascorbic acid, fatty acids, polyphenols (tocopherols, anthocyanins, flavonoids, aromatic oxyacids)) antioxidants [1]. An increase in plant antioxidant activity influences positively on both the ability to grow faster as well as resist stresses of different origins [2-3]. Antioxidant activity has been intensively studying in crop species [4-6] and medicinal plants [7-8].

Previously we produced transgenic canola plants using our own Agrobacterium tumefaciensmediated protocol and $\mathrm{pICH} 3744$ vector which was kindly provided by Icon Genetics (Halle, Germany) [9]. The feature of this genetic construction was a location of the coding sequence for $B A R$ gene without its own promoter near the right border of $\mathrm{T}$ DNA and between two lox $\mathrm{A}$ and $\mathrm{M}$ sites which were the elements of Cre/lox recombination system of $\mathrm{P} 1$ phage. The BAR gene from Streptomyces hygroscopicus confers resistance to Bayer's herbicides with phosphinothricin (PPT, glufosinate) as active ingredient. These herbicides inhibit glutamine synthase [10] that plays a key role in assimilation of nitrogen and regulation of its metabolism in plants. SOD activity, as a measure of antioxidant activity, has been determined in seeds of commercial herbicide-resistant varieties of canola and maize and compared to activity of the untransformed progenitors [11]. We studied SOD activity in leaf tissue of transgenic canola plants expressing the lox-dependent BAR gene [12] in non-stress conditions. This parameter, however, has not yet been explored under stress (herbicide application). In addition, data concerning total radical scavenging activity in herbicide-resistant plants are absent. Investigation of these characteristics assist in determining if there are unintended biochemical changes in transgenic canola plants in comparison with untransformed canola plants.

\section{Materials and methods}

Plant material and growth conditions. Spring canola plants cv Kalinovskii were used as the controls for transgenic ones (lines $\mathrm{T}_{3} 5 / 44 / 1$ and $\mathrm{T}_{3} 5 / 44 / 2$ ). Analyzed transformants were homozygous plants from the third generation. They were produced after self-pollination of primary lines and chosen as ones demonstrating the highest resistance to Basta herbicide treatment under greenhouse conditions among seven tested lines from the $\mathrm{T}_{1}$ generation. Plants were grown on agar-solidified MS medium without hormones [13] in Magenta $^{\mathrm{TM}}$ Boxes under in vitro conditions $\left(+23^{\circ} \mathrm{C}, 4000-\right.$ 5000 lux, 14 (light) /10 (dark) h). The upper buds were also cultured on MS media supplemented with phosphinothricin $(10 \mathrm{mg} / \mathrm{L})$. Sterile solution of herbicide was added to the media after autoclaving. After four weeks of growth the fresh weight (FW), total soluble protein content, total radical scavenging activity, and SOD activity were measured. Fresh leaves $(100 \mathrm{mg}$ ) was ground with $1 \mathrm{~mL}$ of 50 $\mathrm{mM}$ Tris- $\mathrm{HCl}$ buffer $(\mathrm{pH}$ 8.0) in a mixer mill Retsch MM 400 (Germany) with a vibration frequency of $25 \mathrm{~Hz}$ for $3 \mathrm{~min}$ and then centrifuged at $13000 \mathrm{~g}\left(4^{\circ} \mathrm{C}\right)$ for $15 \mathrm{~min}$. The supernatant was used for the analyses.

Determination of total soluble protein (TSP) content. TSP was determined using Bradford's method [14] with bovine serum albumin (Fermentas, Lithuania) as a standard. The optical density of the reaction mixture was detected at $595 \mathrm{~nm}$ by BioPhotomether Eppendorf, v.1.35 (Germany).

SOD activity assay. SOD activity was measured using a method of nitroblue tetrazolium photo- 
chemical oxidation [15] with slight modifications [12]. The absorbance by the reaction mixture in illuminated probes was read at $550 \mathrm{~nm}$ by BioPhotomether Eppendorf (Germany) versus the ones of dark probes.

Total radical scavenging activity assay. A DPPH (2,2-diphenyl-1-picrylhydrazyl) assay was used for total radical scavenging activity evaluation [16]. Reactions were conducted in 96-well microplates [17].

Statistical analysis. The experiments were repeated three times independently, and each data point was the mean of three replicates. The mean, standard deviation, confidence interval and Student's t-test for statistical significance were calculated using Microsoft ${ }^{\circledR}$ Office Excel 2003 (Microsoft Corporation) standard functions.

\section{Results and discussion}

We have analyzed some growth and biochemical parameters of transgenic canola plants expressing the lox-dependent $B A R$ gene. Despite the introduction of the $B A R$ gene without its own promoter, transformed canola shoots were regenerated and selected on media containing phosphinothricin [9]. It had been supposed that expression of the target gene occurred due to its special location in the vector, namely near the right border of T-DNA and between two lox sites [18]. Transgenic $\mathrm{T}_{3} 5 / 44 / 1$ and $\mathrm{T}_{3} 5 / 44 / 2$ lines and untransformed control plants produced fresh weight without differences when they were cultivated on media without phosphinothricin (Fig. 1 A).

The upper buds of control plants had no ability to photosynthesis, bleached, formed no roots, and died under herbicide pressure but transgenic lines formed roots and new green leaves. Transgenic plants produced similar fresh weight on media both with phosphinothricin and without this herbicide (Fig. 1 A). Similar results were obtained for N. tabacum [19-20], tomato (Lycopersicon esculentum) and potato (Solanum tuberosum) [19] that expressed the $B A R$ gene introduced via other vectors. Fresh shoot weight exhibited no significant difference in transformed Lotus corniculatus shoots expressing $B A R$ gene when they were grown in vitro before and after Basta application [21].

Leaves of 28-day-old plants were used for biochemical analyses. TSP content was similar in plants tested under normal growth conditions (Fig. 1B). No significant changes were detected in transgenic plants under growth on the media with PPT as well as after cultivation without it.
SOD activity exhibited no significant differences in leaves of control $\left(25.2 \pm 1.5 \mathrm{U} \mathrm{mg}^{-1}\right.$ protein) and transgenic canola plants $(24.8 \pm 1.2$ and $26.0 \pm 0.9 \mathrm{U} \mathrm{mg}^{-1}$ protein for $\mathrm{T}_{3} 5 / 44 / 1$ and $\mathrm{T}_{3} 5 / 44 / 2$, respectively) in growth on MS medium. Furthermore, the changes in SOD activity were not detected in transgenic plants grown with PPT or in its absence (Fig. 2A). When SOD activity was tested in commercial canola seeds, an decrease in SOD activity by $25 \%$ was shown for plants of MS1/RF1 event and no significant changes were detected for ones of MS8/RF3 event [11].

Both events have the BAR gene in their nuclear genomes. Most transgenic plants including ones expressing heterologous $S O D$ genes possess SOD activity similar to initial plants in non-stress conditions [22]. Sometimes it was lower as in the case of FeSOD overproducing tobacco plants which showed approximately one-half of the endogenous FeSOD activity that was found in nontransgenic plants [23]. Increase in SOD activity due to heterologous gene expression may reach up to 5-fold but the transgenic canola plants failed to survive past the first generation [24]. There are two groups of transgenic canola plants obtained in our experiments characterized by elevated SOD activity under normal growth conditions [12]. They expressed heterologous human interferon alpha $2 \mathrm{~b}$ gene (HuInf- $\alpha 2 b)$ and CYP11Al gene for cytochrome $\mathrm{P} 450_{\mathrm{SCC}}$ from bovine adrenal cortex mitochondria. Improved tolerance to osmotic and heat stresses for these plants in comparison with untransformed ones has been demonstrated [25-26].

The results of the DPPH assay revealed no significant differences between the control and the $B A R$ gene canola plants cultivated without herbicide addition nor transgenic lines grown on media with or without PPT (Fig. 2 B). Antioxidant activity of canola leaves measured as total radical scavenging activity is higher than most other crops [27]. $B$. napus plants possessing antioxidant activity up to 4-fold higher than in original controls have been obtained as a result of introduction PAPI (Production of Anthocyanin Pigment 1) gene from Arabidopsis thaliana into the canola nuclear genome [28]. These transgenic plants exhibited purple leaves. Differences in their coloration depended on changes in anthocyanin synthesis induced by expression of the heterologous $P A P 1$ gene. The $B A R$ gene was used as the selective marker in the vector bearing the PAPl gene. It had no influence on antioxidant activity in the obtained transgenic canola plants. In our experiments expression of lox- 
dependent $B A R$ gene in canola plants produced no significant changes in total radical scavenging activity in comparison with untransformed plants under normal growth conditions. In addition, simi- lar results from the DPPH assay were detected in transgenic plants grown on media with or without phosphinothricin.

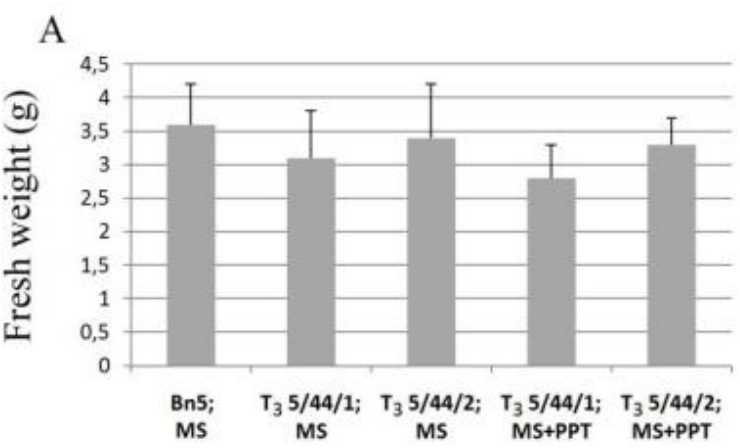

Plant lines and culture medium

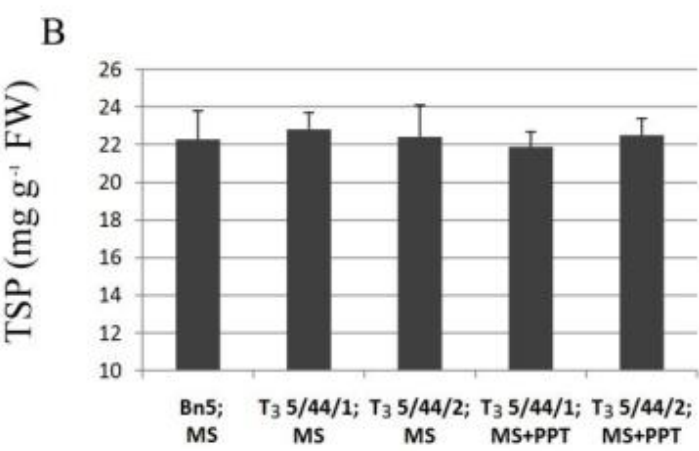

Plant lines and culture medium

Fig. 1. Fresh weight of canola shoots grown in vitro for four weeks on agar solidified MS media with or without PPT (A) and total soluble protein content (B) in their leaves. Here and in Fig. 2: Bn5 are control plants cv Kalinovskii; T3 5/44/1 and T3 5/44/2 are transgenic plants expressing lox-dependent BAR gene. Error bars represent mean \pm one standard deviation from three replications.

A

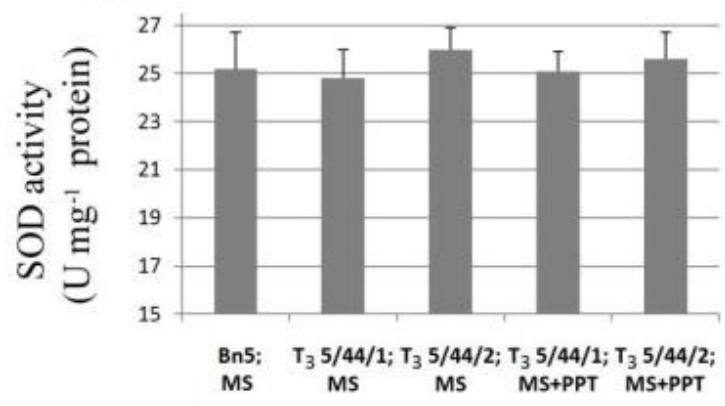

Plant lines and culture medium
B

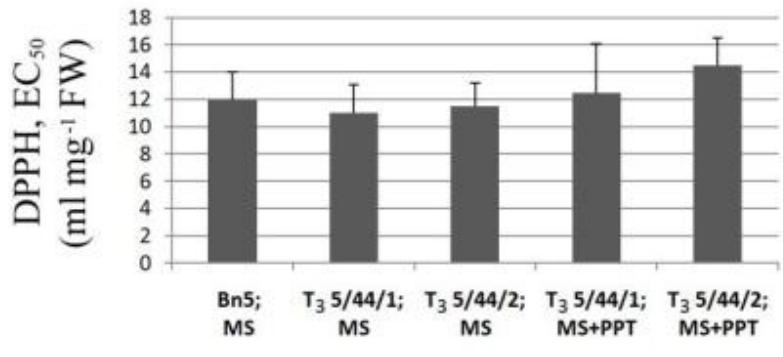

Plant lines and culture medium

Fig. 2. SOD activity (A) and total radical scavenging activity (DPPH assay) (B) in canola leaves when shoots were grown in vitro for four weeks on agar solidified MS media with or without PPT.

\section{Conclusions}

We have found no significant differences in antioxidant activity from leaf extracts of untransformed canola plants under in vitro growth conditions in comparison with ones of phosphinothricinresistant plants of the $T_{3}$ generation. This lack of effect was found for total radical scavenging activity measured by DPPH-assay and SOD activity evaluated photometrically using a nitroblue tetrazolium assay. No significant changes in parameters investigated were observed in transgenic plants cultivated on media with herbicide addition compared to ones grown on media without herbicide. Fresh weight and total soluble protein content were similar in transgenic and untransformed canola plants under growth without phosphinothricin. Thus, loxdependent $B A R$ gene introduction and expression resulted in no significant differences in leaf antioxidant activity in transgenic canola plants comparing to untransformed controls.

Authors appreciate Dr. Valeriia B. Belokurova (Institute of Cell Biology and Genetic Engineering National Academy of Sciences of Ukraine, Kyiv) for improving English in the manuscript. 


\section{References}

1. Hasanuzzaman M., Hossain A.M., Teixeira da Silva J.A., Fujita M. Plant response and tolerance to abiotic oxidative stress: antioxidant defense is a key factor. In: B. Venkateswarlu et al. (eds.). Crop stress and its management: perspectives and strategies. - 2012. - Springer Netherlands. - P. 261-315.

2. Gusta L.V., Benning N.T., Wu G., Luo X., Liu X., Gusta M.L., McHughen A. Superoxide dismutase: an all-purpose gene for agri-biotechnology // Mol. Breed. - 2009. - V. 24 (2). - P. 103-115. doi: 10.1007/s11032-009-9274-y.

3. Rai A.C., Singh M., Shah K. Effect of water withdrawal on formation of free radical, proline accumulation and activities of antioxidant enzymes in ZAT12-transformed transgenic tomato plants // Plant Physiol. Biochem. - 2012. - V. 61. - P. $108-114$. doi: 10.1016/j.plaphy.2012.09.010.

4. Boo H.-O., Heo B.-G., Gorinstein S., Chon S.-U. Positive effects of temperature and growth conditions on enzymatic and antioxidant status in lettuce plants // Plant Sci. - 2011. - V. 181 (4). - P. 479-484. doi: 10.1016/j.plantsci.2011.07.013.

5. Mohamed A.A., Castagna A., Ranieri A., di Toppi L.S. Cadmium tolerance in Brassica juncea roots and shoots is affected by antioxidant status and phytochelatin biosynthesis // Plant Physiol. Biochem. - 2012. - V. 57 (1). - P. 15-22. doi: 10.1016/j.plaphy.2012.05.002.

6. Sharma P., Bhatt D., Zaidi M.G.H., Saradhi P.P., Khanna P.K., Arora S. Silver nanoparticle-mediated enhancement in growth and antioxidant status of Brassica juncea // Appl. Biochem. Biotech. - 2012. - V. 167 (8). - P. 2225-2233. doi: 10.1007/s12010-012-9759-8.

7. Aquil F., Ahmad I., Mehmood Z. Antioxidant and free radical scavenging properties of twelve traditionally used Indian medicinal plants // Turk. J. Biol. - 2006. - 30 (3). - P. 177-183.

8. Krishnaiah D., Sarbatly R., Nithyanandam R. A review of the antioxidant potential of medicinal plant species // Food bioprod. process. - 2011. - V. 89 (3). - P. 217-233. doi: 10.1016/j.fbp.2010.04.008.

9. Sakhno L.A., Gocheva E.A., Komarnitskii I.K., Kuchuk N.V. Stable expression of the promoterless bar gene in transformed rapeseed plants // Cytol Genet. - 2008. -V. 42 (1). - P. 21-28. doi: 10.1007/s11956-008-1003-7.

10. Lea P.J., Joy K.W., Ramos J.L., Guerrero M.G. The action of 2-amino-4-(methylphosphiny)-butanoic acid (phosphinothricin) and its 2-oxoderivative on the metabolism of cyanobacteria and higher plants // Phytochem. - 1984. - V. 23 (1). - P. 1-6. doi: 10.1016/0031-9422(84)83066-6.

11. Xu W., Guo F., Zhou X., Shang Y., Yuan Y., Zhang F., Huang K. Unintended effects were investigated in antioxidant activity between genetically modified organisms and their nontransgenic control // Afr. J. Biotechnol. - 2011. - V. 10 (46). - P. 92729279 .

12. Sakhno L.O., Slyvets M.S. Superoxide dismutase activity in transgenic canola // Cytol Genet. - 2014. - V. 48 (3). - P. 145149. doi: $10.3103 / \mathrm{S} 0095452714030104$.

13. Murashige T., Skoog F. A revised medium for rapid growth and bioassays with tobacco tissue cultures // Physiol Plant. - 1962. - V. 15 (3). - P. 473-497. doi: 10.1111/j.1399-3054.1962.tb08052.x.

14. Bradford M.M. A rapid and sensitive method for the quantitation of microgram quantities of protein utilizing the principle of protein-dye binding // Anal. Biochem. - 1976. - V. 72 (2). - P. 248-254. doi: 10.1016/0003-2697(76)90527-3.

15. Beyer W.F., Fridovich I. Assaying for superoxide dismutase activity some large consequences of minor changes in conditions // Anal. Biochem. - 1987. - V. 161 (2). - P. 559-566. doi: 10.1016/0003-2697(87)90489-1.

16. Blois M.S. Antioxidant determinations by the use of a stable free radical // Nature. - 1958. - V. 181 (4617). - P. 1199-1200. doi: 10.1038/1811199a0.

17. Сахно Л.О., Листван К.В., Кучук М.В. Антиоксидантна активність листків біотехнологічного ріпаку (Brassica napus L.) зі стійкістю до гербіцидів на основі гліфосату і глюфозінату // Вісн. Харк. нац. аграр. ун-ту. - 2015. - Т. 3, № 36. - C. 62-70.

18. Shcherbak N., Kishchenko O., Sakhno L., Komarnytsky I., Kuchuk M. Lox-dependent gene expression in transgenic plants obtained via Agrobacterium-mediated transformation // Cytol. Genet. - 2013. - V. 47 (3). - P. $145-155$. doi: 10.3103/S0095452713030079.

19. De Block M., Botterman J., Vandewiele M., Dockx J., Thoen C., Gossele V., Movva N.R., Thompson C., Montagu M.V., Leemans J. Engineering herbicide resistance in plants by expression of a detoxifying enzyme // EMBO J. - 1987. - V. 6 (9). P. 2513-2518.

20. Spivak S.G., Berdichevets I.N., Yarmolinsky D.G., Maneshina T.V., Shpakovski G.V., Kartel N.A. Construction and characteristics of transgenic tobacco Nicotiana tabacum L. plants expressing CYP11A1 cDNA encoding cytochrome P450 $0_{\mathrm{SCC}} / / \mathrm{Rus} \mathrm{J}$ Genet. - 2009. - V. 45 (9). - P. 1067-1073. doi: 10.1134/S1022795409090075.

21. Savić J., Platiša J., Dragićević M., Nikolić R., Mitić N., Cingel A., Vinterhalter B. The activity of peroxidases and superoxide dismutases in transgenic phosphinothricin-resistant Lotus corniculatus shoots // Arch. Biol. Sci. - 2010. - V. 62 (4). - P. 10631070. doi: 10.2298/ABS1004063S.

22. Kingston A.H., Foyer C.H. Overexpression of Mn-superoxide dismutase in maize leaves leads to increased monodehydroascorbate reductase, dehydroascorbate reductase and glutathione reductase activities // J. Exp. Bot. - 2000. - V. 51 (352). P. 1867-1877. doi: 10.1093/jexbot/51.352.1867.

23. Van Camp W., Capiau K., van Montagu M., Inze D., Slooten L. Enhancement of oxidative stress tolerance in transgenic tobacco plants overproducing Fe-superoxide dismutase in chloroplasts // Plant Physiol. - 1996. - V. 112 (4). - P. $1703-1714$. doi: 10.1104/pp.112.4.1703.

24. Basu U., Good A.G., Taylor G.J. Transgenic Brassica napus plants overexpressing aluminium-induced mitochondrial manganese superoxide dismutase cDNA are resistant to aluminium // Plant Cell Environ. - 2001. - V. 24 (12). - P. $1269-1278$. doi: 10.1046/j.0016-8025.2001.00783.x. 
25. Slyvets M., Sakhno L. Human interferon alpha $2 \mathrm{~b}$ positively affects canola growth in both aseptic non-stressed and water deficit conditions // IJBSANS. - 2014. - V. 1 (5). - P. 104-118.

26. Sakhno L.O., Slyvets M.S., Kuchuk M.V. Cyp11A1 canola plants under heat stress conditions // Cytol Genet. - 2014. - V. 48 (5). - P. 279-284. doi: 10.3103/S0095452714050090.

27. Chen I.-C., Chang H.-C., Yang H.-W., Chen G.-L. Evaluation of total antioxidant activity of several popular vegetables and chinense herbs: a fast approach with $\mathrm{ABTS} / \mathrm{H}_{2} \mathrm{O}_{2} / \mathrm{HRP}$ system in microplates // J Food Grug Analysis. - 2004. - V. 12 (1). P. 29-33.

28. Li X., Gao M.-J., Pan H.-Yu, Cui De-J., Gruber M.Y. Purple canola: Arabidopsis PAPI increases antioxidants and phenolics in Brassica napus leaves // J. Agric. Food Chem. - 2010. - V. 58 (3). - P. 1639-1645. doi: 10.1021/jf903527y.

SAKHNO L.O. ${ }^{1}$, LYSTVAN K.V. ${ }^{2}$

${ }^{I}$ SI "Institute of Food Biotechnology and Genomics» NAS of Ukraine,

Ukraine, 04123, Kyiv, Osipovskogo str., 2A, e-mail: sakhno2007@ukr.net

${ }^{2}$ Institute of Cell Biology and Genetic Engineering NAS of Ukraine,

Ukraine, DSP-22, 03680, Kyiv, Zabolotnogo str., 148, e-mail: lystvan@ukr.net

\section{ANTIOXIDANT ACTIVITY IN BRASSICA NAPUS L. PLANTS EXPRESSING LOX-DEPENDENT BAR GENE}

Aim. The study of possible unintended biochemical peculiarities of newly obtained herbicide-resistant canola (Brassica napus L.) plants expressing the lox-dependent BAR gene was the aim. Methods. Total soluble protein content, total free radical scavenging activity, and superoxide dismutase activity have been investigated using Bradford's, DPPH, and nitroblue tetrazolium assays, respectively. Fresh weight of plants grown on media with or without phosphinothricin was also measured. Results. The antioxidant activity of leaf extracts of untransformed plants under in vitro growth conditions had no significant differences in comparison with ones of phospinothricin-resistant plants in the third generation. No significant changes in parameters investigated were observed in transgenic plants cultivated on media with herbicide addition compared to ones grown on media without it. Fresh weight and total soluble protein content were similar in transgenic and untransformed canola plants under growth without phosphinothricin. Conclusions. Lox-dependent BAR gene introduction and expression resulted in no significant differences in leaf antioxidant activity in transgenic canola plants comparing to untransformed controls.

Keywords: Brassica napus, antioxidant activity, DPPH, glufosinate, superoxide dismutase. 